\title{
Hakekat dan Batasan-Batasan Gharar Dalam Transaksi Maliyah*
}

(Nature and Gharar Limits In Maliyah Transactions)

\author{
Muh. Fudhail Rahman ${ }^{1}$
}

doi $10.15408 /$ sjsbs.v5i3.9799

\begin{abstract}
:
Gharar is an important term in muamalat business practices. As Imam Nawawi stated when commenting on the hadith of Imam Muslim about the prohibition on gharar buying and selling, that the prohibition on gharar buying and selling is something very urgent in the discussion points about buying and selling. Generally, the problem of prohibited buying and selling is caused by containing gharar. The practice of business transactions that once existed in the early days of Islam returned again in the present. Basically, the forms and patterns in buying and selling practices that are oriented to profit both individually and collectively up to various fraudulent practices and detrimental to other parties is the repetition of the band of history. In this paper, try to describe the nature of the theory of buying and selling gharar.
\end{abstract}

Keywords: Gharar, Buy and Sell, Muamalat

\begin{abstract}
Abstrak:
Gharar menjadi satu term larangan penting dalam praktek bisnis muamalat. Sebagaimana yang diutarakan oleh Imam Nawawi ketika berkomentar atas hadis riwayat Imam Muslim tentang larangan jual beli gharar, bahwa larangan pada jual beli gharar adalah sesuatu yang sangat urgen dalam pokok-pokok pembahasan tentang jual beli. Umumnya problematika jual beli yang terlarang disebabkan karena mengandung gharar. Praktek transaksi bisnis yang pernah ada di masa awal-awal Islam kembali berulang pada masa sekarang. Secara mendasar bentuk dan pola dalam praktek jual beli yang berorientasi untuk mencari untung baik secara individu maupun kolektif hingga ke berbagai praktek culas dan merugikan pihak lain adalah pengulangan kembali pita sejarah. Pada tulisan ini, mencoba mendeskripsikan tentang teori hakekat jual beli gharar.
\end{abstract}

Kata Kunci: Gharar, Jual Beli, Muamalat

*Diterima: 12 September 2018, Revisi: 2 Oktober 2018, Dipublikasi 19 Desember 2018.

${ }^{1}$ Muh Fudhail Rahman adalah Dosen Tetap Bidang Hukum Ekonomi Syariah Fakultas Syariah dan Hukum UIN Syarif Hidayatullah Jakarta. E-mail: fudhail.rahman@uinjkt.ac.id. 


\section{Pendahuluan}

Gharar menurut etimologi berasal dari kata غرّ يغرّ غرّا وغرورا Orang yang terlibat dan menjadi objek (karena merasakan rugi) dalam praktek gharar disebut عَرْرَّر بوَغرِيْر atau pihak yang merasa ditipu dan telah mengkonsumsi sesuatu yang tidak halal. ${ }^{2}$ Atau terjerumus ke dalam suatu kesalahan yang disangkanya benar.

Istilah turunan lain adalah ghurur, berarti seseorang yang telah memperdayakanmu, baik dari golongan manusia maupun setan. Sebagaimana firman Allah Swt al-Fatir: 5 ; "ولا يغرنكم باله الغرور. Artinya: “...Dan janganlah (setan) yang pandai menipu, memberdayakan kamu tentang Allah." Ayat ini menerangkan bahwa setan sebagai pelaku akan menggoda dan memberdayakan manusia ke dalam perangkapnya. Bisa pula dalam arti membahayakan, baik kepada diri sendiri maupun harta. Artinya membuka peluang untuk menjadi hancur/bahaya tanpa diketahui. Isimnya adalah gharar. ${ }^{3}$ Gharar bermakna bahaya, dan taghrir bermakna menjerumuskan diri ke dalam gharar. ${ }^{4}$

Adapun menurut istilah, banyak ulama yang telah memberi batasan makna terhadap gharar yang nampak saling berbeda tetapi memiliki kedekatan pengertian. Di antaranya adalah:

1. Al-Khattabi: "Sesuatu yang tidak diketahui akibatnya, inti dan rahasianya tersembunyi." 5 Dalam defenisi menunjukkan kepada kita bahwa setiap jual beli yang maksudnya tidak diketahui dan tidak jelas takarannya adalah termasuk kategori gharar. Misalnya membeli ikan dalam kolam, atau burung yang lagi terbang di udara dan transaksi-transaksi lain yang tidak bisa diketahui hasil akhirnya. Semuanya ini bisa membuat jual beli menjadi fasakh. ${ }^{6}$ Penjabaran gharar sangatlah luas, yang kesemuanya itu bisa disimpulkan dalam bentuk ketidaktahuan pada pihak-pihak yang bertransaksi.

2. Ibnu Mundhir berpendapat bahwa sesungguhnya Rasulullah Saw yang telah melarang jual beli gharar yang termasuk di dalamnya cabangcabang jual beli. Hal tersebut terjadi pada semua jual beli yang diakadkan

${ }^{2}$ Ibnu Mandzur, Lisan al-'Arab, (Bairut: Dar al-Sadir, t.t. juz. 5) 11

3 Atabik Ali dan Ahmad Zuhdi Muhdloi, Kamus Kontemporer Arab Indonesia, (Yogyakarta: Pondok Pesantren Krapyak, cet. 3, 1998), 1347.

${ }^{4}$ Ibnu Manzur, Lisan al-'Arab, (Beirut: Dar Sadr, jil. 5, cet. 3, 1993), 11, dan Ibrahim Mustafa, Mu'jam al-Wasit (Istanbul: Dar al-Da'wah, jil. 2, tt), 648. Lihat juga al-Fairuz Abadi, alQamus al-Muhit, http://www.alwarraq.com, al-Maktabah al-Syamilah, juz. 1, tt, h. 474.

${ }^{5}$ Abu Sulaiman Hamdi bin Muhammad al-Khattabi al-Busti, Ma'alim al-Sunan Sharh Sunan Abu Dawud, (Beirut: Dar al-Kutub al-`Ilmiyah, Cet. 1 Jil.3, 1991), 75.

${ }^{6}$ Mazhab Hanafiyah membagi jual beli yang tidak sah kepada dua macam, yaitu jual beli bathil dan fasakh. Jual beli bathil bila tidak terpenuhi salah satu rukun jual belinya. Sedangkan fasakh, adalah tidak terpenuhinya salah satu syarat atau lebih. 
oleh pihak-pihak yang bertransaksi dan mengandung ketidaktahuan baik pada penjual dan pembeli, maupun salah satu di antara keduanya. ${ }^{7}$

3. Imam Nawawi menjelaskan, "Larangan Rasulullah atas transaksi gharar merupakan sesuatu yang sangat pokok dan penting dalam jual beli. Oleh sebab itu, Imam Muslim menempatkannya di awal pada kitab shahihnya. Banyak kasus jual beli bahkan tidak terbatas jumalhnya yang masuk dalam kategori gharar. misalnya jual beli yang mengandung cacat, jual beli yang tidak ada barangnya, tidak diketahui obyeknya, tidak mampu diserahterimakan, jual beli yang tidak dimiliki secara sempurna oleh penjual, jual beli ikan dalam kolam yang berisikan banyak air, air susu yang diperah dan berbagai macam jual beli lainnya. Semuanya adalah jual beli bathil karena mengandung gharar dan tidak dalam keadaan mendesak. ${ }^{8}$

4. Ibnu al-Athir berkata, "Gharar adalah sesuatu yang zahirnya dapat mempengaruhi dan dalamnya dibenci. Zahirnya membuat tidak jelas pada diri pembeli dan dalamnya tidak diketahui." ${ }^{\prime 9}$

5. Al-Azhari berpendapat, "Gharar adalah bila tidak diiringi dengan ikatan dan kepercayaan. Al-Asmai' menambahkan bahwa yang termasuk dalam kategori gharar, jual beli yang kedua belah pihak yang bertransaksi tidak ketahui intinya, hingga pada akhirnya mereka tahu kekurangannya."10

6. Ibnu Taimiyah mendefenisikan, gharar adalah "Yang tidak diketahui hasil akhirnya."11 Defenisi ini menggambarkan sesuatu yang ujungnya tersembunyi dan urusannya kabur. Hasilnya meragukan di antara bisa terwujud dan tidak. Bila hasil akhirnya baik bagi pembeli, maka maksud akad terlaksana. Tapi sebaliknya, bila tidak terwujud maka maksud akad tidak terlaksana. Dalam kitab Nazariyat al-'Aqd disebutkan bahwa gharar pertaruhan antara kemungkinan bisa terwujud dan tidak. Inilah yang dimaksud dengan tersembunyi atau kabur hasil akhirnya. Kondisi seperti ini semuanya berpulang kepada sampainya obyek transaksi ke tangan pembeli dan penjual menerima timbal baliknya. ${ }^{12}$ Penjelasan ini sesungguhnya menegaskan pendapat beliau ketika mendefenisikan tentang gharar.

${ }^{7}$ Abu Bakar bin Muhammad bun Ibrahim bin al-Mundzir al-Naisaburi, Al-Ausat fi alSunan wa al-Ijma' wa al-Ikhtilaf, Tahqiq oleh Dr. Sagir Ahmad bin Muhammad Hanif, (Riyad: Dar Tayyibah, Cet. 2, 1998), h. 314.

${ }^{8}$ Sahih Muslim Bisharhi al-Nawawi (Kairo: Dar al-Rayyan, Jil. 10, 1407H), 156.

${ }_{9}$ Majiduddin Ubai al-Sa'adat al-Mubarak bin Muhammad bin al-Utsair al-Jazari, Jami alUsul fi Ahadits al-Rasul Saw, Tahqiq oleh Abd al-Qadir al-Arnaut (Damaskus: Dar al-Bayan, jil. 10, 1969), 156.

10 Rashid Abdul Rahman al-`Ubaidi (Tahqiq),Almustadrak tahdzib al-Lugha Lilazhari, h.83-84.

${ }^{11}$ Ibnu Taimiyah, Majumu' Fatawa, Tahqiq oleh Abdul Rahman bin Muhammad bin Qasim, (Madinah Munawwarah: Majma' al-Malik Fahd, tt.

${ }^{12}$ Ibnu Taimiyah (syaikh al-Islam) Nazariyat al-'Aqd, (Beirut: Dar al-Ma'rifah, tt), 224. 
7. Senada dengan gurunya, Ibnu al-Qayyim ${ }^{13}$ menerangkan tentang gharar, "Sesuatu yang diragukan dapat berhasil atau tidak. Atau dalam ungkapan lain, sesuatu yang informasinya tersembunyi dan tidak diketahui obyeknya."14 Ibnu al-Qayyim menambahkan bahwa jual beli gharar adalah mensandarkan sumber kepada obyeknya. Seperti halnya jual beli al-Malaqih ${ }^{15}$ dan al-Madamin. ${ }^{16}$ Misalnya, jual beli barang yang memiliki cacat sehingga tidak bisa diserahterimakan, jual beli kuda yang lagi lepas, burung diudara dan lain-lain. Semuanya ini bisa disimpulkan sebagai sesuatu yang tidak diketahui hasil akhirnya, tidak bisa diserahterimakan dan tidak diketahui pasti obyek dan takarannya. ${ }^{17}$

8. Sedangkan Ibn 'Abidin mengatakan, "Gharar adalah sesuatu yang diragukan keberadaan obyeknya." 18

9. Menurut Adiwarman Karim, "Gharar sama dengan taghrir adalah situasi di mana terjadi incomplete information karena adanya uncertainty to both parties (ketidapastian dari kedua belah pihak yang bertransaksi). Pihak yang bertransaksi tidak memiliki kepastian mengenai apa yang ditransaksikan, atau mengubah sesuatu yang pasti (certain) menjadi tidak pasti (uncertainty).

Membaca defenisi-defenisi di atas, nampak bahwa pada hakekatnya praktek gharar bisa merugikan pihak-pihak yang terlibat dalam transaksi, baik pembeli maupun penjual. Sesuatu yang merugikan tersebut pada awalnya tersembunyi sehingga sangat memungkinkan keduanya akan merasakan kerugian, atau salah satu pihak dirugikan di atas keuntungan pihak lainnya. Penulis melihat bahwa gharar meliputi dua bentuk, yaitu: pertama, meragukan keberadaan obyek antara bisa dicapai atau tidak. Kedua, bentuknya yang tidak diketahui, baik pada sifat, takaran, timbangan dan semacamnya. Kedua bentuk ini bermuara pada satu kesimpulan bahwa gharar mengandung bahaya sebagaimana pada defenisi etimologinya. Mencermati lebih dalam terhadap defenisi-defenisi di atas, lebih mengarah kepada makna gharar secara umum. Meskipun ada perbedaan dari sisi pengungkapan.

${ }^{13} \mathrm{Ibnu}$ al-Qayyim adalah murid dari Ibnu Taimiyah.

${ }^{14}$ Ibnu al-Qayyim al-Jauzi, Zad al-Ma'ad fi Hadyi Khair al-'Ibad, Tahqiq Shu'aib alArnauti dan Ba'du al-Qadir al-Arnauti (Beirut: Muassasah al-Risalah, Cet. 14, jil. 5, 1996), 822.

${ }^{15}$ al-Malaqih adalah jual beli air mani pejantan yang nantinya dapat disuntikkan kepada betinanya. Jual beli cairan seperti ini tidak diperbolehkan karena mengandung gharar, atau adanya ketidakjelasan dan karaguan apakah penggunaan cairan ini akan dapat jadi sesuai harapan saat disuntikan ke cairan betina.

${ }^{16}$ al-Madamin adalah jenis jual beli pada obyek yang masih belum jelas atau tersembunyi sehingga tidak bisa dilihat. Misalnya, jual beli janin binatang yang masih dalam perut induknya. Ataupun jual beli apa saja yang tidak bisa disaksikan langsung. Jelas, seperti ini masuk kategori gharar.

${ }^{17} \mathrm{Ibnu}$ al-Qayyim al-Jauzi, Zad al-Ma'ad,... jil. 5, 818.

${ }_{18}$ Muhammad Amin al-Shahir bi Ibnu 'Abidin, Hashiyah Rad al-Mukhtar 'ala al-Dar alMukhtar, (Mesir: Matba'ah Mustafa al-Bab al-Halabi, Cet. 2, jil. 5, 1386 H), 62. 
Nampaknya, para ulama belakangan dalam mendefenisikan tentang gharar, sejalan dengan apa yang diutarakan oleh Ibnu Taimiyah dan al-Sarkhasi, bahwa gharar adalah bila hasil akhirnya tersembunyi. Bisa dilihat kepada beberapa defenisi yang juga menyebutkan contoh-contoh kasus tentang gharar bahwa gharar adalah tersembunyi hasil akhirnya dan adanya keraguan pada dua probabilitas. ${ }^{19}$

Hasil akhir yang tersembunyi sangat dipengaruhi oleh adanya informasi yang tidak sempurna pada mereka yang bertransaksi. Seperti defenisi Zamir Iqbal dan Abbas Mirakhor, gharar adalah situasi di mana pihak-pihak yang terikat kontrak atau salah seorang dari mereka tidak memiliki informasi berkaitan dengan sebagian pasal dalam akad atau pasal kontrak, dan cenderung tidak mampu dikontrol oleh salah satu pihak. ${ }^{20}$ Bagi Adiwarman Karim, hal ini menunjukkan bahwa gharar bersumber dari persoalan ketidaksamaan pada informasi pada pihak-pihak yang bertransaksi, sehingga melahirkan ketidakpastian yang diciptakan oleh kekurangan informasi atau tidak adanya kontrol dalam akad. Gharar dianggap sebagai pengabaian terhadap unsur esensi dalam transaksi. Misalnya pada kepastian harga jual, kesanggupan penjual menyerahkan barang jualannya, tempat dan waktu jual beli serta lain sebagainya. Adanya gharar dalam sebuah transaksi menjadikan akad tersebut batal dan tidak berlaku lagi. ${ }^{21}$

Adapun defenisi yang bermakna ragu terhadap ada dan tidaknya obyek, seperti defenisi Ibnu 'Abidin, hanya terbatas pada keberadaan obyek. Tapi, tidak menerangkan tentang sifat maupun berapa jumlahnya. Misalnya, saya menjual salah satu dari dua barangku kepadamu, tapi tidak menentukan salah satunya.

Demikian pula dengan defenisi yang barangnya tidak diketahui. Seperti defenisi Ubay Muhammad bin Hazm, yang berkata bahwa gharar adalah "Sesuatu yang dalam akadnya tidak diketahui pasti berapa kuantitas dan sifat obyek." 22 Defenisi ini hanya menyebutkan tentang sifat dan jumlah obyek, tapi tidak menerangkan kepastian ada tidaknya obyek. Contohnya adalah kasus jual beli kuda yang lepas dari kandangnya. Akad ini menjelaskan tentang sifat dan seberapa banyak obyek yang diperjualbelikan, tapi sangat memungkinkan untuk tidak mampu diserahterimakan di antara pihak yang berakad. Baginya, kasus ini adalah contoh gharar. tapi berbeda dengan Ibnu Hazm, yang membolehkan contoh kasus di atas. ${ }^{23}$

\footnotetext{
${ }_{19}$ Muhammad Siddiq Hasan Khan al-Qanuji, Al-Raudah al-Nadiyah Sharh al-Darar alBahiyah, Riyad: Maktabah al-Kautsar, Cet. 4, jil. 2, 1996., h.197.

20 Zami Iqbal dan Abbas Mirakhor, An Introduction To Islamic Finance: Theory and Practice, (Terj. Oleh A.K. Anwar dengan judul Pengantar Keuangan Islam: Teori dan Praktek, (Jakarta: Kencana, Cet. 1, 2008), 88.

${ }^{21}$ Adiwarman Karim, Islamic banking: Figh and Financial Analysis, Jakarta: Rajawali Press, Ed. 4, 2011. h.31

${ }^{22}$ Ibnu Hazm al-Zahiri, al-Mahalli , Tahqiq: Ahmad Muhammad Shakir, Cairo: Maktabah Dar al-Turats, jil. 8, tt., h.389.

${ }^{23}$ Ibnu Hazm al-Zahiri, al-Mahalli ,... h.388.
} 
Pemilahan yang lain atas beberapa defenisi yang diungkap oleh para ulama bisa dibedakan sebagai berikut :

Pertama: “Tampaknya sesuatu secara tidak haqiqi, tapi disifatkan dengan suatu kriteria yang sebenarnya tidak ada padanya. Tujuannya agar mempengaruhi pihak lain agar menyetujui atas apa yang ditransaksikan". ${ }^{24}$

Kedua, "Melakukan transaksi pembelian terhadap suatu obyek, dan pembeli memahami bahwa transaksinya sudah sempurna tanpa cacat, tapi ternyata masih ada ketidakjelasan". ${ }^{25}$

Ketiga, "Munculnya ketidakjelasan dari sisi ungkapan akad, atau transaksi bohong, bertujuan mempengaruhi salah satu pihak yang bertransaksi untuk setuju atas akad yang dilakukan". ${ }^{26}$

Tiga macam defenisi di atas, dapat dikatakan bahwa setiap dari defenisi tersebut tidak meliputi atau menggambarkan secara utuh dari sisi makna serta macam-macam gharar itu sendiri. Justru defenisi-defenisi tersebut membuat batasan-batasan gharar semakin sempit. Misalnya, pada defenisi kedua, gharar hanya dimaknai sebagai perilaku salah dari sisi praktek perbuatan saja.

Sedangkan defenisi pertama, lebih dominan mengarah kepada gharar perkataan ketimbang gharar dengan perbuatan (disifatkan dengan suatu kriteria yang sebenarnya tidak ada padanya). Meskipun defenisi ini nampak mencakup gharar perkataan dan perbuatan sehingga membuat nya lebih baik dari pada defenisi kedua, tapi terasa masih cenderung kepada gharar perkataan.

Semoga yang paling utuh menggambarkan tentang gharar adalah defenisi ketiga. Defenisi ini dengan jelas mencakup perkataan dan perbuatan (akad dan transaksi bohong). Namun, sebagai catatan terhadap defenisi ketiga ini, penulis melihat adanya batasan gharar terhadap perkataan dan perbuatan saja, padahal secara esensi tidak selamanya penyebab gharar bersumber dari kedua hal itu. Menelusuri paparan dari mazhab Hanafiyah dan Syafi'iyah, mereka tidak menetapkan adanya khiyar (pilihan memilih atas aib) pada gharar perkataan. Oleh sebab itu, tidak cukup hanya gharar pada perkataan saja. Hal tersebut berbeda dengan gharar perbuatan pada sebagian penjelasannya.

Tiga macam defenisi yang digambarkan di atas hanya menempatkan gharar bersumber dari kedua belah pihak yang bertransaksi. Padahal, diketahui bahwa gharar bisa jadi terjadi tidak dari pihak yang bertransaksi saja, tapi juga bisa dari perantara, petunjuk-petunjuk pelaksanaan akad, wakil atau kurator dan lain-lain.

Cakupan keseluruhan makna gharar sebagaimana yang dipahami dari beberapa defenisi di atas, adalah yang dilontarkan oleh Dewan Pengkaji Fikih alIslami pada Organisasi Konfrensi Islam dalam pertemuan tahunan di Makkah al-

${ }^{24}$ Abdullah Muhammad bin Yusuf al-Mawwaq, Al-Majallah al-'Adliyah (Beirut: Dar alKutub al-'Ilmiyah, cet. 1, Lihat pula, Ahkam al-Mu'amalat al-Shar'iyah h. 377-380.

${ }^{25}$ Al-Taj wa al-Iklil (jil. 6), h. 349. Lihat pula Abdul Karim al-Rafii, Fath al-'Aziz sharh alWajiz , dikutip dalam kitab al-Majmu' Sharh al-Muhadzdzab (Beirut: Dar al-Fikr jil. 8, tt), h. 333.

${ }^{26}$ Mustafa al-Zarqa, al-Madkhal al-'Am ( jil. 1), h. 379. 
Mukarramah tahun 2010, "Gharar adalah ketidakjelasan dari salah satu pihak yang berakad atau dari pihak lain terkait dengan objek yang berhubungan dengan transaksi mereka, sehingga dalam akad tidak sesuai dengan apa yang seharusnya berjalan, baik melalui perkataan maupun perbuatan, yang bila mereka tahu akan ketidakpastian tersebut, pasti akan menarik diri dari apa yang mereka telah transaksikan." 27

Perbedaan ulama terhadap gharar berangkat dari pemahaman dan cakupan kandungan mereka terhadap jual beli gharar (بيع الغرر). Ada yang memahami istilah ini hanya terkait dengan obyek yang ditransaksikan, karena ghararnya hanya berhubungan dengan saat terjadinya transaksi. Namun, dominan ulama memahami ghararnya itu sendiri bersumber dari sifat akad. Sehingga cakupannya selain termasuk obyek transaksi pada saat berlangsungnya akad, juga terkait dengan sifat-sifat yang muncul akibat terjadinya akad. Cakupan luasnya ini menunjukkan bahwa jual beli gharar terkait dengan semua jenis larangan yang potensi ghararnya ada. Seperti jual beli melempar batu (يع (1), dimana tempat jatuhnya menjadi pembatas atas keputusan jual beli. Ini adalah gharar dari sifat akad. Selanjutnya, gharar dari sighat. Misalnya, jual beli dua transaksi dalam satu akad (البعتين في بيعة), atau jual beli syarat (بيع الشرط).28

Mencermati lebih jauh kepada defenisi tentang gharar, sebagaimana pandangan Imam Nawawi, penulis sepakat dengan pernyataan Khalid bin Abdul 'Aziz al-Batili, yang menjelaskan bahwa gharar sangatlah penting diketahui karena berkonsekuensi luas terhadap praktek jual beli di masyarakat. ${ }^{29}$ Adapun kasus dan cabang praktek gharar seakan tidak berbatas, bisa ditinjau dari sisi sifat luar obyek maupun keadaan obyek itu sendiri. Ini pula yang disebut oleh Wahbah al-Zuhaili bahwa makna jual beli gharar luas yang mencakup sifat.

Dalam kitab al-Furuq, ${ }^{30}$ gharar dapat diklasifikasi menjadi tiga, yakni pertama: gharar katsir (excessive gharar); yaitu jenis ketidakjelasan tingkat teratas yang kadar ketidakjelasannya cukup tinggi. Misalnya, transaksi penjualan ikan yang masih ada di dalam kolam karena belum bisa dilihat dan diketahui kualitas dan kuantitas secara jelas sehingga sangat mungkin terjadi kekeliruan saat menebak. Transaksi jenis ini jelas dilarang dan haram hukumnya. ${ }^{31}$ Misalnya;

${ }^{27}$ Abdullah al-Salami, al-Taghrir fi al-Mudarabat fi Bursah al-Auraq al-Maliyah Tausifuhu wa Hukumuh, Workshop ke-20 Majlis al-Fiqh al-Islami yang diadakan di Makkah al-Mukarramah 25-29 Desember 2010, (Makkah al-Mukarramah: Rabitah al-'Alam al-Islami, Majma' al-Fiqh alIslami, tt) h. 9.

${ }^{28}$ Wahbah al-Zuhaili, Mausu'ah al-Fiqhi al-Islami wa al-Qadayah al-Mu'asirah, Damaskus: Dar al-Fikir al-Mu'asir, Jil. 4, Cet. 1, 2010. H. 198.

${ }^{29}$ Khalid bin Abdul 'Aziz al-Batili, Ahadits al-Buyu' al-Manhiyu 'anha, (Riyad: Dar alKunuz Isybiliya, Cet 1, 2004), 53.

30 (Ibnu Rajab, al-Furuq, 3/265).

${ }^{31}$ Dalam kajian fikih klasik, transaksi kategori gharar katsir (excessive) yang benar-benar dilarang syariah yaitu antara lain; (i) ba'i al-madamin: adalah jual-beli benih yang akan jadi dari seekor ternak jantan setelah terjadinya perkawinan dengan induk betina. (ii) ba'i al-malaqih: 
menjual bayi binatang yang masih dalam perut induknya tanpa menjual induknya sekaligus, menjual barang yang tidak jelas jenisnya, akan menyerahkan biaya pembelian tapi tidak menentukan waktunya secara jelas, dan lainnya. Kedua: gharar qalil (negligible); yaitu jenis ketidakjelasan di mana kadar ketidakjelasannya hanya sedikit saja sehingga kemungkinannya dapat ditolerir dan diterima oleh kedua belah pihak yang terlibat dalam satu transaksi, seperti jual-beli batu baterai yang tingkat kekuatan pakainya tidak dapat ditentukan dengan pasti sampai berapa lama ketahanannya, jual rumah meski tidak pembeli tidak melihat langsung pondasinya, sewa rumah sebulan padahal terkadang 28 , 29, 30 dan 31 hari dalam sebulan, dan semisalnya. Jenis transaksi yang mengandung gharar qalil (gharar kecil) atau diistilah dengan slight gharar (gharar yang diabaikan) ini dibolehkan oleh para ulama.

Ketiga : gharar mutawassit (pertengahan); yaitu jenis ketidakjelasan yang berada di antara kedua jenis gharar tersebut di atas, terkadang bisa dikategorikan dalam peringkat qalil ataupun katsir tergantung kepada kasuskasus tertentu. Misalnya; menjual sesuatu yang tersembunyi dalam tanah, menjual sesuatu secara lump sum, pembeli membayar barang sebelum serah terima objek, jual beli barang tanpa menghadirkan barang, dan lain-lain.

Macam-macam bentuk jual beli gharar: ${ }^{32}$

1. Gharar dilihat dari aspek akad dan efeknya. Seperti, jual beli al-Hasha, jual beli al-Mulamasah dan jual beli al-Munabadzah.

2. Gharar dilihat dari aspek harga dan kuantitasnya. Seperti, jual beli dua jenis barang yang saling berbeda (tapi tidak menentukan), dan jual beli yang tidak menyebutkan harga.

adalah jual-beli indung telur dari ternak betina yang tersebut belum mengandung. (iii) ba'i habl alhablah: adalah jual-beli anak ternak yang masih ada dalam kandungan induknya. (iv) ba'i almulamasah: adalah jual-beli barang yang dilakukan dengan menyentuhkan tangan pada salah satu barang di antara sekian banyak barang yang sama dan barang yang disentuh itulah menjadi obyek transaksi atas harga yang sudah dibayar di muka. (v) ba'i al-munabazah: adalah jual-beli dengan cara menutup mata dan mengambil salah satu barang dan kemudian dilemparkan ke suatu tempat tertentu. Barang yang dilempar itulah menjadi obyek yang dibeli atas harga yang sudah dibayar di muka. (vi) ba'i al-hasah: adalah jual-beli dengan melemparkan sebuah batu kerikil ke atas barangbarang tertentu di mana barang yang terkena lemparan kerikil tersebut menjadi obyek transaksi yang harganya telah dibayar di muka. (vii). ba'i darbah al-qanis: jual-beli barang yang akan dihasilkan dari lemparan jala/jaring ke dalam laut. Ikan atau hewan yang terjaraing akan menjadi obyek transaksi yang pembayarannya dilakukan terlebih dahulu. (viii) ba'i darbah al-gais: jual-beli yang dilakukan penyelam mutiara yang melakukan transaksi sebelum mendapatkan mutiaranya. Jadi sebelum mutiara yang menjadi obyek transaksi wujud dan diperoleh, si penyelam sudah lebih dahulu melakukan transaksi jual-beli. (ix) ba'i al-muzabanah 'araya: Jual-beli korma atau anggur yang masih belum dituai dengan korma atau anggur yang telah dituai kadar kedua jenis barang tersebut didasarkan pada perkiraan saja, bukan dengan timbangan atau takaran tertentu. (x) ba'i al-muhaqalah: jual-beli gandum yang masih belum dituai dengan gandum yang semisalnya dengan kadar pertukaran perkiraan saja.

32 Abu al-Walid Sulaiman bin Khalaf al-Baji, al-Muntaqa Sharh Muwatta', Jeddah: Maktabah al-Andalusi, jil. 5, tt., h. 41. 
3. Gharar dilihat dari aspek ketidaktahuan atas sifat-sifat barang. Seperti, jual beli air susu yang belum diperah dan jual beli al-Madamin dan al-Malaqih.

4. Gharar dilihat dari aspek tidak mampu diserahterimakan. Seperti, jual beli ikan dalam kolam.

5. Bisa pula gharar dari aspek masa pelunasan harga. Seperti jual beli yang pelunasannya diundur hingga waktu luang atau hingga meninggalnya pembeli, dan semacamnya.

Gharar dari sisi etimologi الخطر yang artinya bahaya sepadan dengan istilah yang berarti menjerumuskan diri ke dalam bahaya. Misalnya, adanya pernyataan membahayakan diri sendiri dan hartanya tanpa disadari. Perbedaan makna gharar dapat dilihat dari makna defenisi terminologi yang diungkap oleh ulama: ${ }^{33}$

1. Memaknai gharar terbatas pada sesuatu yang tidak diketahui pasti apakah akan terjadi atau tidak terjadi. Tidak termasuk dalam makna defenisi ini sesuatu yang tidak diketahui wujudnya. Misalnya defenisi Ibnu 'Abidin :

Artinya: "Gharar adalah ragu terhadap wujud barang yang diperjualbelikan".

2. Memahami gharar pada sesuatu yang tidak diketahui. Tidak termasuk sesuatu yang diragukan apakah terjadi atau tidak. Misalnya defenisi Ibnu Hazm:

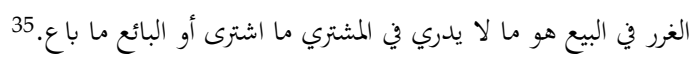

Artinya: "Gharar pada jual beli adalah adalah sesuatu yang tidak diketahui oleh pembeli apa yang dibelinya dan penjual tidak mengetahui apa yang dijualnya".

3. Menggabung dua defenisi sebelumnya, yaitu mencakup sesuatu yang tidak diketahui hasil akhirnya dan objeknya. Pendapat ini diperpegangi oleh aliran al-Dzahiriyah. Misalnya defenisi al-Sarakhsi:

$$
\text { الغرر ما يكون مستور العاقبة.36 }
$$

Artinya: "Gharar adalah sesuatu yang kabur hasilnya akhirnya". Inilah pendapat yang banyak diperpegangi oleh para ulama.

33 Siddiq Muhammad al-Amin al-Darir, Al-Gharar fi al-'Uqud wa Atsaruhu fi al-Tatbiqat al-Mu'asirah, (Saudi Arabiyah: al-Ma'had al-Islami Lilbuhuts wa al-Tadrib [IDB], Cet. 1, 1993), 11. Buku ini diterjemahkan ke dalam bahasa inggris dengan judul Al-Gharar in Contracts and Its Effect on Contemporary Transactions, terbit tahun 1997.

${ }^{34}$ Muhammad Amin bin 'Umar 'Abidin al-Shahir bi Ibni 'Abidin, Radd al-Muhtar 'ala alDurr al-Mukhtar, Penerbit Bulaq, jil. 4, 1836., h. 147.

${ }^{35}$ Ibnu Hazm al-Zahiri, al-Mahalli ,... jil. 8., h. 343, 439, 489.

${ }^{36}$ Muhammad bin Ahmad bin Sahal al-Sarkhasi, Al-Mabsut, Mesir: Penerbit al-Sa'adah, jil. 13, 1047., h. 194. 
Defenisi terakhir mencakup semua hal yang disebutkan oleh ulama lain saat memberi batasan pengertian gharar. cakupan yang luas tersebut pada akhirnya banyak diperpegangi oleh ulama selanjutnya. Sebagaimana, termaktub pula dalam rujukan al-Mi'yar al-Shar'i tentang pengertian gharar:

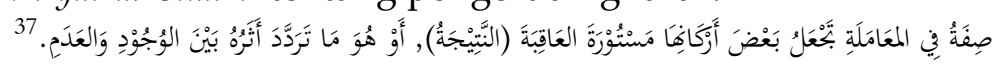

Artinya: "Salah satu sisi dalam muamalat yang membuat beberapa bahagiannya menutupi sebagian akibatnya. Atau menjadikan hasil akhirnya tidak jelas antara ada dan tidak".

\section{Hakekat dan Hukum Gharar}

Imam Nawawi dalam penjelasannya dalam kumpulan hadis shahih Muslim, menyebutkan bahwa jual beli gharar adalah pokok dan dasar dalam kitab jual beli. Ada beberapa hadis yang terkait, salah satunya adalah ${ }^{38}$ :

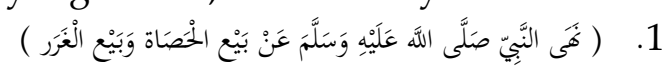

Artinya, "Nabi Saw melarang jual beli hasat ${ }^{39}$ dan jual beli gharar ${ }^{40 \prime}$.

Efek negatif yang ditimbulkan oleh jual beli gharar amat luas, sebagaimana pendapat Khalid bin Abdul 'Aziz al-Batili"1. Imam Nawawi juga memiliki pandangan sama yang mengawali interpretasinya dengan hadis larangan jual beli gharar dan memasukkan banyak persoalan muamalah yang seolah-olah tidak terbatas. Misalnya, jual beli barang yang cacat, atau barang yang tidak ada, yang tidak diketahui bentuk dan tempatnya, sesuatu yang tidak mampu diserahterimakan, atau menjual sesuatu yang tidak dimiliki secara sempurna. Misalnya, adalah jual beli ikan dalam kolam yang melimpah airnya, susu binatang yang belum diperah, jual beli janin hewan yang masih dalam perut induknya, jual beli sebagian barang yang masih ditumpuk, jual beli potongan pakaian dan semacamnya. Kesemuanya ini merupakan jual beli tidak dibenarkan alias bathil karena kebutuhan terhadap jual beli tersebut sifatnya tidak jelas.

Demikian pula transaksi pada obyek barang bergerak yang lagi dalam masa penyewaan, jual beli barang yang tidak ada barangnya, yang tidak diketahui wujudnya, yang tidak dapat diserahterimakan, komoditi barang yang

${ }^{37}$ Al-Mi'yar al-Shar'i No. 31, “Dabit al-Gharar al-Mufsid Lilmu'amalat al-Maliyah”. 502.

${ }^{38}$ Abu Zakariyah Yahya bin Syarif bin Mari al-Nawawi, al-Minhaj Sharh Sahih Muslim bin al-Hajjaj (Sharh al-Nawawi ‘ala Sahih Muslim), (Beirut: Dar Ihyai al-Turath al-'Arabi, Juz. 10, Cet. 2, 1972), h. 156.

39 Jual beli hasat adalah kebiasaan masyarakat arab jahiliyah yang mensanda rkan keputusan memilih barang, baik dari sisi besar, luas atau banyaknya barang tersebut, disesuaikan dengan hasil lemparan, atau tempat jatuhnya batu. Macam-macamnya (i) Pembeli berkata kepada si penjual: Jika aku lempar batu ini berarti jual beli jadi. (ii) Penjual berkata kepada si pembeli: Jual beli berlaku atas barang yang jatuh padanya lemparan batumu. (iii) Pembeli atau penjual berkata: Ukuran tanah yang berlaku dalam jual beli ini berlaku sejauh lemparan batumu.

${ }^{40}$ Makna gharar, seperti yang disebutkan pada pengertian tentang gharar.

${ }^{41}$ Khalid bin Abdul 'Aziz al-Batili, Ahadits al-Buyu' al-Manhiyu 'anha,... 53. 
tidak dimiliki secara sempurna oleh penjual dan sejenisnya...", 42 Menurut Imam Nawawi, mengutip pandangan ulama lain, bahwa batalnya beberapa jual beli tersebut disebabkan oleh gharar. Sementara, beberapa lainnya dibolehkan bila kandungan ghararnya sedikit, atau sesuatu yang tidak bisa disaksikan tapi ia bagian yang tidak terpisahkan dari objek barang". ${ }^{43}$

Penjelasan Imam Nawawi di atas, memberi indikasi bahwa praktek gharar dalam transaksi perdagangan cukup penting dan urgen diangkat dan dibahas. Meminimalisir praktek gharar, merupakan bagian penting bagi terwujudnya keadilan dalam roda bisnis kehidupan. Betapa banyak bentuk dan ragam jual beli yang marak dalam dunia bisnis, tidak semua dapat dipastikan bahwa ia sesuai dengan hukum syari'ah. Dan larangan-larangan transaksi tersebut umumnya diindikasikan mengandung gharar. Pada tahap penentuan boleh dan tidak, para ulama secara umum memadang bahwa akad yang dilarang adalah memiliki unsur gharar yang banyak (fahish). Sedangkan, yang kriteria ghararnya terhitung sedikit (yasir) dan tidak bisa disaksikan, transaksinya sendiri dibolehkan meskipun ia bagian yang tidak terpisahkan dari objek barang. ${ }^{44}$ Seperti, jual beli gedung dengan pondasi bangunan yang tidak bisa disaksikan.

Namun, lanjut Nawawi bahwa ada kalanya sesuatu yang sifatnya tidak jelas dibolehkan manakala kebutuhan terhadapnya mendesak. Seperti, jual beli rumah yang sulit diketahui atau dilihat langsung kualitas pondasi serta kerangka besi yang sudah tertutup oleh material bangunan lainnya, jual jual beli hewan yang sedang bunting dan memiliki banyak susu. Maka, baik pondasi, besi maupun susu dari contoh di atas adalah dibolehkan karena sifatnya adalah bukan sebagai obyek pokok yang ditransaksikan. Tapi ia hanya sebagai (kebetulan ada) pengikut terhadap obyek yang diperjualbelikan. ${ }^{45}$ Dan ada kebutuhan yang pasti terhadap pokok barang. Sedangkan, yang mengikuti sulit untuk dilihat langsung.

Sama dengan pendapat ulama lainnya, bahwa penyebab batalnya transaksi di atas karena gharar. Sebaliknya, bila ketidakjelasan tersebut sulit dipenuhi, sedangkan ada keperluan mendesak kepadanya, maka termasuk dalam kategori gharar yang kecil. Ada kategori lain yang diperdebatkan ulama, yaitu misalnya menjual suatu obyek yang tidak ada di tempat saat terjadinya transaksi, seperti menjual binatang yang lagi digembalakan di padang rumput. Sebagian ulama memandangnya sebagai gharar yang kecil, dan menganalogikan kepada jual beli pesanan yang memang barangnya belum ada, sehingga

42 Sharh Sahih Muslim, 10/156-157.

${ }^{43}$ Sharh Imam Nawawi ‘ala Sahih Muslim, jus. 5, h. 296.

44 Abu Zakariyah Muhyiddin Ibn Sharaf al-Nawawi, Al-Majmu' Sharh al-Muhadhab, (Matba'ah al-Tadamun al-Akhwa, Juz 6, 676H), h. 288.

يغتفر في التوابع مالا يغتفر في غيرها Hal ini sejalan dengan salah satu qaidah fikih yang mengatakan (Dapat dimaafkan pada hal yang mengikuti, tapi tidak pada yang lainnya) 
dibolehkan. Sementara, sebagian ulama lain melihatnya bukan transaksi gharar yang kecil, sehingga membatalkan jual beli itu.

Dari pemaparan ini, dapat dipahami bahwa ulama muslim sepakat atas kebolehan transaksi yang mengandung gharar yang sedikit. Diantaranya, ulama menyepakati transaksi jual beli gharar yang dilarang adalah bila kandungan ghararnya lebih dominan sehingga transaksi itu sendiri lebih dikenal dengan jual beli gharar. Dalam suatu transaksi yang mengandung makna transaksi murni atau transaksi yang mengandung gharar, maka akan terjadi tarik menarik diantara keduanya. Yang lebih besar pengaruhnya itulah yang lebih dikenal karena lebih mendominasi. ${ }^{46}$ Adapun, transaksi yang lebih sedikit unsur ghararnya, disepakati oleh para ulama atas kebolehannya sesuai dengan kebiasaan aplikasinya di masyarakat ('urf). ${ }^{47}$

Pandangan beberapa ulama telah memperkuat argumentasi di atas. Di antaranya, Abu Abbas al-Qurtubi : “Setiap bentuk jual beli pasti mengandung gharar. Tapi jika porsi ghararnya sedikit dan tidak dimaksudkan dalam transaksi tersebut, maka syariah mengabaikannya/membolehkannya." 48

Imam Nawawi menjelaskan : "Adakalanya unsur gharar dalam suatu transaksi diabaikan bila ada kepentingan terhadapnya. Seperti ketidaktahuan terhadap pondasi rumah yang tidak nampak oleh mata, atau jual beli kambing yang memiliki susu karena hamil." 49 Kasus pondasi rumah di atas dibolehkan karena kebutuhan terhadapnya dan tidak bisa dilihat oleh mata. Demikian pula dengan air susu pada kambing diperjualbelikan. Demikian pula, unsur yang sepele atau yang tidak terlalu penting. Misalnya; dalam transaksi sewa menyewa, baik rumah maupun kendaraan selama sebulan penuh. Padahal, dalam sebulan bisa tiga puluh atau dua puluh sembilan hari. Termasuk masa sekarang, tarif tol yang sama pada jarak yang berbeda antara jauh atau dekat dan tidak terlalu berjauhan. Menurut para ulama, lanjut Imam Nawawi, bahwa sebab sah atau tidak sahnya suatu transaksi akibat gharar adalah tergantung kepada unsur besarnya pengaruh gharar dalam transaksi tersebut. Bila ada mashalat dan unsur gharar tidak bisa diabaikan selain menjalankannya, dan besar ghararnya kecil, maka transaksi tersebut dibolehkan. Bila gharar menjadi bagian penting dan menjadi tujuan, maka transaksi itu tidak sah.

Baik Ibnu al-Qayyim maupun Ibnu Taimiyah sama-sama berendapat bahwa, "Tidak semua gharar menjadi sebab diharamkannya sesuatu. Gharar

${ }^{46}$ Abu Zakariyah Yahya bin Syarif bin Mari al-Nawawi, al-Minhaj Sharh Sahih Muslim bin al-Hajjaj (Sharh al-Nawawi 'ala Sahih Muslim), .... h. 157. Lihat pula Abu al-Walid Muhammad bin Ahmad bin Rushdi al-Qurtubi, Al-Muqaddimat al-Mumahadat Libayan ma iqtadathu rusum al-Muadawwanah min al-Ahkami al-Syar'iyat wa al-Tahsyilat al-Muhakkamat Liummahati Masailuha al-Mushkilat, Beirut: Dar al-Maghrib al-Islami, jil. 2, cet. 1, 1408H. H. 71.

${ }^{47}$ Khalid bin Abdul 'Aziz al-Batili, Ahadits al-Buyu'... 54

${ }^{48}$ Ibnu Jazyi al-Garnati al-Maliki, Qawanin al-Ahkam al-Sar'iyah, Tahqiq: Abdul Rahman Hasan Mahmud, Cairo: Maktabah 'Alam al-Fikr, Cet. 1, 1986., h. 259. Lihat pula Shihabuddin alQarafi, Al-Furuq, Beirut: Dar al-Ma'rifah, jil. 3, tt, h. 265.

${ }^{49}$ Sahih Muslim Bi Sharh al-Nawawi, Kairo: Dar al-Rayyan, 1407, juz 10, 156 
yang sedikit atau sesuatu yang tidak bisa dihindari, adalah tidak mencederai sahnya transaksi". Selain itu, meskipun ghararnya banyak tetap dibolehkan bila adanya kebutuhan mendesak dan musti dilalui tanpa bisa dihindari. ${ }^{50}$

Oleh sebab itu, memahami beberapa penjelasan ulama di atas, akan dapat menjawab beberapa persoalan dan problematika yang terdapat dalam transaksi muamalah. Ditegaskan oleh Imam Nawawi, bahwa perbedaan dan perdebatan justru muncul pada besar kecilnya gharar yang dikandung. ${ }^{51}$ Demikian pula argumentasi Ibnu Rusydi al-Jad; "Sesungguhnya, perbedaan yang terjadi dikalangan ulama terkait dengan tidak sahnya akad dalam transaksi muamalah adalah besarnya pengaruh gharar yang dikandung. Gharar yang dimaksud apakah menjadi bagian yang dominan sehingga masuk dalam kategori larangan dalam hadis Nabi Saw tentang pelarangan transaksi akibat gharar. Ataukah gharar yang dikandung, masuk kategori sedikit sehingga tidak mempengaruhi sah tidaknya suatu akad transaksi. ${ }^{52}$

Sebagai kesimpulan, bahwa yang dilarang adalah persentasi kandungan ghararnya dominan. Gharar yang dimaksud terkait langsung dengan transaksi pokok, dan bukan sebagai pengikut. Keberadaan dan berjalannya transaksi yang mengandung gharar tidak dalam keadaan dharurat untuk dilaksanakan.

Maka sangat bisa dipahami dan tidak diragukan lagi bahwa adanya larangan dalam transaksi yang mengandung gharar mengandung hikmah yang sangat besar. Hikmah itu sendiri adalah dalam rangka menghindari permusuhan, perselisihan dan pergesekan di antara pelaku ekonomi. Akad-akad transaksi yang terjadi akan berjalan secara jelas dan transaparan tanpa perlu khawatir ada yang dicurangi dan ditipu dalam komitmen bisnis mereka.

Dalam jual beli gharar, secara implisit akan melahirkan kezaliman, pertikaian dan permusuhan. Konsekuensinya adalah memakan harta orang lain secara batil. Firman Allah Swt; QS. Al-Nisa (4): 29.

"Hai orang-orang yang beriman, janganlah kamu saling memakan harta sesamamu dengan jalan yang batil, kecuali dengan jalan perniagaan yang Berlaku dengan suka sama-suka di antara kamu. dan janganlah kamu membunuh dirimu ${ }^{53}$; Sesungguhnya Allah adalah Maha Penyayang kepadamu."

Demikian pula pada ayat QS. Al-Baqarah (2): 188, yang artinya: “Dan janganlah sebahagian kamu memakan harta sebahagian yang lain di antara kamu dengan jalan yang bathil dan (janganlah) kamu membawa (urusan) harta itu kepada hakim, supaya kamu dapat memakan sebahagian daripada harta benda orang lain itu dengan (jalan berbuat) dosa, Padahal kamu mengetahui.

${ }^{50}$ Ibnu al-Qayyim al-Jauziyah, Zad al-Ma'ad fi Hadyi Khair al-'Ibad, Muhaqqiq: Shuaib alArnaut. Beirut: Muassasah al-Risalah, jil. 5, Cet. 14, 1407. 820. Lihat pula Abu al-Farji Abdurrahman bin Rajab al-Hanbali, Al-Qawa'id al-Nuraniyah, Beirut: Dar al-Ma'rifah, tt., h. 83.

${ }^{51}$ Sahih Muslim Bi Sharh al-Nawawi, Jil. 10,... 157.

${ }^{52}$ Abu al-Walid Muhammad bin Ahmad bin Rashad al-Qurtubi, Al-Muqaddimat alMumahadat, Penerbit al-Sa'adah jil. 2, 1325., h. 73.

${ }^{53}$ Larangan membunuh diri sendiri mencakup juga larangan membunuh orang lain, sebab membunuh orang lain berarti membunuh diri sendiri, karena umat merupakan suatu kesatuan. 
Ibnu 'Arabi berkata bahwa makna batil dalam ayat tersebut berarti tidak dibenarkan oleh syara' dan tidak membawa manfaat. Agama melarangnya dan tidak membenarkannya. Mengharamkan transaksi yang mengandung gharar, riba dan semacamnya.

Sebagaimana hukum gharar yang diungkap di atas, adalah dilarang bila peresentasi ghararnya banyak, sebaliknya bila sedikit maka diperbolehkan. Hadis larangan gharar, sabda Rasulullah Saw.

$$
\text { أن رسول الله صلى الله عليه وسلم: فى عن بيع الغرر. }
$$

Artinya: "Rasulullah Saw melarang jual beli Gharar".

Menurut Imam Nawawi bahwa hadis ini merupakan pokok bahasan pada bab jual beli dan mencakup banyak permasahalan yang sangat luas. Hadis ini juga menjadi dasar dillarangnya gharar dalam berbagai akad transaksi.

Gharar terjadi apabila, kedua belah pihak saling tidak mengetahui apa yang akan terjadi bila transaksi tersebut dijalankan. Islam sejak awal melarang trasaksi demikian karena berpotensi mendzalimi salah satu pihak. Oleh sebab itu, misalnya dalam transaksi jual beli, Islam telah menetapkan beberapa syarat sah, yang tanpa salah satu syarat itu akan dapat membatalkan atau tidak sahnya jual beli. Diantaranya ditegaskan oleh Imam Nawawi ${ }^{55}$ :

1. Timbangan harus jelas, baik berat maupun jenis barang yang ditimbang.

2. Barang dan harga yang dijelas pula. Tidak diperbolehkan harga yang tidak diketahui jelas oleh pihak-pihak yang bertransaksi.

3. Memiliki waktu tangguh yang dimaklumi.

4. Kedua belah pihak sama-sama ridha terhadap bisnis yang dijalankan.

Melihat hadis larangan praktek gharar di atas, jelas bahwa dimana ada gharar, maka dapat merusak akad. Larangan gharar dalam Islam memiliki peran untuk menjamin keadilan. Ini bisa dilihat pada contoh-contoh klasik yang disebutkan ulama-ulama terdahulu. Misalnya, jual beli burung yang lagi terbang di udara. Meskipun secara fisik sehat dan ukurannya mungkin bisa diperkirankan. Demikian pula dengan jumlahnya. Tapi tidak ada jaminan apakah bisa diserahterimakan atau tidak. Seperti jual beli burung yang sedang tidak dalam penguasaan penjual, dapat mencederai kesempurnaan jual beli tersebut. Dalam kondisi seperti itu, pasti akan ada pihak yang dirugikan. Sedangkan, pihak lain untung.

Terdapat tiga hukum terkait dengan hadis di atas, sebagaimana dijelaskan oleh para ulama:

${ }^{54}$ HR. Abu Hurairah, Ibnu 'Umar, Ibnu Abbas, Abu Sa'id dan Anas dengan perbedaan dari sisi pelafadzan. Riwayat ini terdapat dala kitab Syarh Shahih Muslim oleh Imam Nawawi 3/152, Sunan Ibnu Majah 2/10, Sunan Abu Dawud 3/346, Tirmidzi 3/532, Syarh al-Suyuti pada Sunan al-Nasai 8/262.

55 Al-Imam al-Nawawi, Sharh al-Muhadzdzab, Beirut: Dar Ihya al-Turats al-'Arabi, jil. 9, tt. h. 210 . 
1. Haramnya jual beli yang mengandung gharar. Hal tersebut dipahami dari bunyi hadis yang melarang, sebagaimana dijelaskan dan pendapat yang masyhur dari ulama ushul..$^{56}$

2. Rusaknya akad jual beli gharar. Yaitu tidak ada kebaikan padanya menurut mayoritas ulama. ${ }^{57}$

3. Mengandung keduanya, yaitu akad haram dan rusak pada setiap akad yang mengandung gharar..$^{58}$

\section{Kriteria gharar yang merusak transaksi}

Ulama telah bersepakat, seperti yang termaktub dalam Mi'yar al-Shar'i $\mathrm{Li}$ al-Mu'amalah al-Maliyah, bahwa ada empat macam aspek yang menyebabkan gharar dilarang. Yaitu, Volume gharar lebih banyak, Gharar hanya terjadi pada transaksi bisnis, Gharar ada pada bagian yang pokok dan tidak ada kebutuhan mendesak. ${ }^{59}$

Sejalan pula dengan pembagian gharar menurut pembahasan sebelumnya, dapat disederhanakan sebagai berikut :

1. Pertama, besarnya cakupan gharar pada suatu transaksi Tingkatan cakupan gharar dapat dibedakan atas tiga tingkatan, yaitu banyak, sedang dan sedikit.

2. Kedua, dari sisi pengaruh gharar, apakah adanya gharar dapat merusak akad transaksi atau tidak.

Siddiq Muhammad al-Amin al-Darir mengemukakan bahwa praktek gharar hanya bisa terjadi pada akad-akad bisnis (mu'awadat), khususnya pada shigat akad, tempat, harga dan waktu pelunasan utang. Jelas bahwa akad yang dipandang banyak mengandung gharar, dapat merusak kebolehan transaksi yang dilakukan. Adapun, gharar pada transaksi sosial (tabarru'), sesuatu yang diberikan kepada pihak lain meskipun mengandung gharar, transaksi tersebut dapat dibenarkan. Alasannya, karena akad yang bersifat sosial didasarkan pada kerelaan masing-masing pihak yang memberi maupun yang menerima. ${ }^{60}$

Telah banyak ulama yang berkomentar tentang larangan jual beli gharar, begitu pula dengan nash-nash yang terkait dengannya, serta bahasan lanjutan atau cabang atas hukum jual beli gharar. Pernyataan para ulama tersebut terhadap transaksi yang mengandung gharar atau tidak, tergantung sejauh mana gharar itu sendiri berpengaruh terhadap sah tidaknya suatu transaksi. Oleh karena itu, mengulangi empat hal diatas bahwa karakteristik atau batasan gharar bisa dilihat sebagai berikut. Keempatnya harus ada pada

${ }^{56}$ Al-Khudri, Usul al-Fiqh, 240.

${ }^{57}$ Al-Amidi, al-Ahkam fi Usul al-Ahkam Lilamidi, 2/275.

${ }^{58}$ Al-Amidi, al-Ahkam fi Usul al-Ahkam Lilamidi, 2/275.

${ }^{59}$ Al-Mi'yar al-Shar'i No. 31, "Dabit al-Gharar al-Mufsid Lilmu'amalat al-Maliyah", 502. Lihat pula Siddiq Muhammad al-Amin al-Darir, Al-Gharar fi al-'Uqud .... 39

${ }^{60}$ Siddiq Muhammad al-Amin al-Darir, Al-Gharar fi al-'Uqud wa Atsaruhu fi al-Tatbiqat al-Mu'asirah, (Saudi Arabiyah: al-Ma'had al-Islami Lilbuhuts wa al-Tadrib [IDB], Cet. 1, 1993), 8. 
transaksi yang dipandang gharar. Bila salah satu batasan gharar di atas luput, atau salah satu unsurnya tidak ada, maka transaksi yang dimaksud tidak dapat dikatakan sebagai gharar. Berikut adalah batasan-batasan dimana gharar dapat membatalkan akad transaksi, yaitu ${ }^{61}$ pertama, Volume gharar lebih banyak. Kedua, Gharar hanya terjadi pada transaksi bisnis. Ketiga, Gharar ada pada bagian yang pokok. Keempat, Tidak ada kebutuhan mendesak terhadapnya.

Berikut adalah pembahasan masing-masing dari ke empat batasan gharar di atas.

1. Volume gharar lebih banyak

Sebagaimana yang disebut sebelumnya, bahwa bahasan ulama yang cenderung berbeda bukan pada penjelasan pokok tentang gharar, tapi ada pada pada praktek dilapangan. Praktek yang dimaksud adalah seberapa besar volume gharar ada dalam tranksaksi. Ulama bersepakat atas larangan gharar yang banyak. Bila volumenya sedikit, mereka tidak mempermasalahkannya. Justru, gharar yang volumenya sedang, atau antara banyak dan sedikit, disinilah terjadi perbedaan luas, di antara mereka ada yang melarang dan ada pula yang membolehkan.

Menurut Siddiq Muhammad al-Amin al-Darir, kategori gharar yang dilarang adalah apabila volume aspek ghararnya lebih dominan, terjadi pada objek transaksi yang utama, dan bukannya pada unsur-unsur sebagai pengiring dari objek utama, serta tidak dijumpainya tanda-tanda dharurat untuk melaksanakan akad yang mengandung gharar. ${ }^{62}$

Berikut adalah contoh-contoh transaksi yang volume ghararnya sedikit, sehingga tidak berpengaruh kepada legalitas akad yang dimaksud.

a. Jual beli buah yang dilapisi oleh kulit, meski tidak melihat isinya langsung.

b. Jual beli rumah tanpa melihat pondasinya.

c. Sewa masuk toilet, tanpa membedakan secara pasti jumlah air yang digunakan serta lamanya berdiam diri di dalamnya.

d. Sewa rumah yang sama pada hitungan perbulan, meskipun ada perbedaan jumlah hari. Adakalanya 29, 30 atau 31 hari. Contoh jual beli yang volume ghararnya lebih banyak

e. Jual beli hisah, mulamasah dan munabadhah.

f. Jual beli janin binatang, tanpa induknya.

g. Jual beli janin yang masih dalam perut induknya.

h. Jual beli jaminan.

i. Jual beli buah sebelum matang.

j. Jual beli yang tidak diketahui barangnya, tanpa pemberian hak kepada pembeli untuk menentukan.

k. Jual beli diketahui jenis barangnya.

${ }^{61}$ Siddiq Muhammad al-Amin al-Darir, Al-Gharar fi al-`Uqud,... 39-47.

${ }^{62}$ Siddiq Muhammad al-Amin al-Darir, Al-Gharar fi al-`Uqud ... 39 
1. Menangguhkan harga barang hingga masa berikutnya secara tidak pasti.

Contoh-contoh di atas menunjukkan bahwa kasus praktek gharar bisa dijumpai pada banyak transaksi, baik pada kandungan ghararnya banyak maupun yang sedikit. Demikian pula pada transaksi yang tingkat kandungan ghararnya adalah sedang, atau diantara yang banyak dan sedikit. Misalnya:

a. Jual beli sesuatu yang masih terpendam dalam dalam tanah.

b. Jual beli tanpa timbangan.

c. Jual beli dengan harga pasar.

d. Jual beli dengan hanya satu harga.

e. Jual beli seseorang sebelum barangnya diserahterimakan.

f. Jual beli hasil pertanian, dimana hasilnya tidak bersamaan, tapi

g. Jual beli sesuatu yang objeknya tidak ada,

h. Pertanian.

Beberapa ulama telah memberi pengertian dan defenisi antara gharar yang banyak dan gharar yang sedikit. Di antaranya, al-Baji mengatakan bahwa gharar yang sedikit adalah : "Sesuatu yang dalam akadnya hampir tidak mengandung atau sedikit saja mengandung gharar." Sedangkan, gharar yang banyak yaitu : "Sesuatu yang dalam akadnya mengandung banyak gharar, sehingga akad itu sendiri disifati dengan gharar." 63

Dua defenisi di atas bisa menunjukkan dua pengertian yang tidak terlalu berbeda. Karena gharar yang sedikit berbunyi hampir mengandung gharar. Sedangkan gharar yang banyak dalam defenisinya berbunyi mengandung banyak gharar, bahkan akadnya disifati dengan gharar, justru memberikan ruang besar terjadinya perbedaan.

Menurut Siddiq Muhammad al-Amin al-Darir, mendefenisikan gharar antara banyak atau yang sedikit kandungan ghararnya adalah sesuatu yang tidak mudah. Saat memberikan defenisi kepada keduanya secara tidak tegas bedanya, maka lebih sulit memberikan pengertian kepada gharar yang kandungannya sedang. Dan pada posisi inilah memberikan ruang besar di kalangan fuqaha untuk berbeda. Adapun bagi Siddiq sendiri lebih memilih mendefenisikan gharar yang banyak dengan,

$$
\text { الغرر الكثير إنه هو الغرر المؤثر, وكل ما عداه فلا تأثير له. }
$$

Artinya, "Gharar yang bisa mempengaruhi (sah tidaknya suatu transaksi), dan selainnya adalah gharar yang tidak berpengaruh." 64

Dan ini cukup sejalan dengan defenisi yang diutarakan oleh al-Baji,

$$
\text { الغرر الكثير هو ما كان غالبا في العقد حتى صار العقد يوصف به. }
$$

\section{1, h.41.}

63 Sulaiman bin Khalaf al-Baji, al-Muntaqa Sharh al-Muwatta', Penerbit as-Sa'adah, Jilid.

${ }^{64}$ Siddiq Muhammad al-Amin al-Darir, Al-Gharar fi al-`Uqud... 41 
Artinya, "Sesuatu yang dalam akadnya mengandung banyak gharar, sehingga akad itu sendiri disifati dengan gharar."

Keistimewaan pengertian terakhir adalah dapat meminimalisir perbedaan dan mengurangi kesimpangsiuran mana gharar yang dapat mempengaruhi sah tidaknya transaksi dan mana gharar yang tidak berpengaruh. Ulama juga menyepakati bahwa kategori gharar yang banyak, sangat berpengaruh terhadap tidak sahnya suatu transaksi. Sebaliknya, transaksi yang kandungan ghararnya sedikit, maka tidak mempengaruhi atau merusak kebolehannya.

2. Gharar hanya terjadi pada transaksi bisnis

Gharar hanya terjadi pada transaksi bisnis saja, misalnya pada akad jual beli, akad kerjasama dan akad sewa-menyewa. Sebagaimana yang dipahami secara umum, bahwa asas bertransaksi adalah semuanya boleh, kecuali bila ada nash yang melarang. Terkait dengan praktek gharar, maka hadis Nabi telah jelas-jelas melarang praktek gharar. tingkatan hadis tersebut adalah shahih, sehingga tidak ada cara lain dalam meresponnya kecuali meninggalkan praktek gharar dalam berbagai macam transaksi bisnis.

Adapun pada jenis akad lain, tidak semua praktek gharar didalamnya dilarang. Misalnya pada akad-akad sosial, meskipun dijumpai ada gharar, tapi tidak akan mempengaruhi sah tidaknya transaksi sosial tersebut. Sebab, nash yang terkait dengan larangan gharar, hanya berhubungan dengan akad-akad bisnis.

Misalnya dalam akad pemberian (hibah), bila saja ada gharar di dalamnya, tidak akan memunculkan permusuhan dan tidak pula memakan harta milik orang lain secara bathil. Seseorang yang memberikan atau menghadiahkan buah apel yang masih belum matang dipohonnya kepada pihak lain, bila saja buahnya jadi semua atau sedikit, maka menjadi milik orang yang diberikan. Sebaliknya, bila tidak jadi, maka tidak akan memberikan kerugian pada pihak yang diberikan. Alasannya adalah dalam transaksi hibah, pihak yang diberikan tidak memberikan sesuatu sebagai pengganti atas buah yang dijanjikan kepadanya. Oleh karena itu, tidak ada alasan untuk marah pihak yang diberikan bila apa yang diinginkan hasil akhirnya justru tidak memberikan hasil apa-apa.

Sangat berbeda dengan transaksi jual beli misalnya, bila apa yang dinantikan tidak sesuai dengan hasil akhirnya, maka pihak yang telah mengeluarkan dananya sebagai ganti atas buah yang ditunggunya, pasti akan merasakan kerugian. Ini sama saja dengan telah mengambil dan memakan harta orang lain dengan bathil. Selanjutnya, akan dapat mengakibatkan pertikaian dan permusuhan. Apalagi bila kerugian yang dialami satu pihak terasa besar dan berat baginya, sehingga ia merasa menyesal dan rugi.

Oleh karena itu, menjadi hikmah besar bila dalam transaksi bisnis ada larangan praktek gharar. gharar itu sendiri adalah ketidakjelasan pada hasil 
akhir dari transaksi yang diinginkan, yang sangat memungkinkan salah satu pihak dirugikan. Dengan larangan gharar pada transaksi bisnis, justru memberikan jaminan dan keamanan kepada pihak-pihak yang bertransaksi dan dapat meminimalisir sebab-sebab munculnya pertikaian dan permusuhan yang diakibatkan oleh akad yang tidak jelas.

3. Gharar ada pada bagian yang pokok

Tidak ada perbedaan di antara ahli fikih, bahwa gharar yang dapat merusak akad adalah bila terjadi pada pokok objek transaksi. Namun, gharar yang ditemukan pada unsur pengikut dari transaksi itu sendiri, tidak akan mempengaruhi legalitas transaksi. Pandangan ini sejalan dengan kaidah fikhiyah yang menyebutkan: يفتقر في التوابع مالا يفتقر في غيرها , artinya sesuatu yang mengikuti butuh kepada apa yang diikutinya, berbeda yang diikuti (tidak butuh keadaan yang mengikutinya). Maksudnya bahwa keadaan sesuatu yang mengikuti tidak akan mempengaruhi pokoknya. Atau yang pokok tidak terpengaruh terhadap apa yang mengikutinya.

Beberapa contoh, sebagai berikut:

a. Jual beli buah yang belum pantas dimakan (biji tunas) sebagai pokok dari obyek yang diperjualbelikan. Artinya bahwa tidak dibenarkan hanya menjual biji buah yang belum menampakkan sesuatu yang layak dimakan. Karena hal tersebut mengandung gharar. Tetapi boleh manakala dijual dengan pokoknya (tanamannya). Dalam hadis Nabi yang bermakna seorang pembeli boleh membeli buah kurma yang masih berbentuk tunas dengan syarat bersama dengan pohonnya sekaligus. Bila pemilik menyetujuinya, maka sah terjadinya jual beli antara buah yang belum layak petik bersama dengan pohonnya. Ini diperkuat oleh argumen Ibnu Qudamah ketika mengurai hadis tersebut, dengan mengatakan bahwa bila pemilik menjual buah tersebut bersama dengan pohonnya, maka tidak ada pihak yang dirugikan, karena kemungkinan ghararnya tidak nyata. ${ }^{65}$

b. Menjual kambing bunting. Menjual janin kambing yang sedang dihamilkan oleh induknya tanpa mengiktusertakan induknya tidak diperbolehkan karena masuk dalam kategori gharar. Sebaliknya, bila berkata misalnya, saya menjual kambing ini yang sedang bunting, maka jual beli tersebut adalah dibenarkan. Adapun janin yang lagi berada dalam perut induknya masuk dalam obyek diperjualbelikan sehingga tidak termasuk dalam kategori gharar. Alasannya, janin yang sedang dalam perut induknya hukumnya adalah tabi' lilmabi', atau janin sebagai pengikut terhadap apa yang diperjual belikan. ${ }^{66}$

\footnotetext{
${ }^{65}$ Abu Muhammad 'Abdullah bin Ahmad bin Muhammad bin Qudamah al-Maqdisi, alMughni, (Dar al-Manar, jil. 4, 1947), h.82.

66 Abu Zakariya Muhyiddin bin Sharf al-Nawawi, al-Majmu' Sharh al-Muhadzdzab, Tahqiq: Muhammad bin Najib al-Muti'i, Cairo: Dar al-Turats al-'Arabi, jil. 9, 1994., h.323.
} 
c. Jual beli apa yang wujudnya ada di dunia. Bahasan ini dibicarakan oleh ulama Hanafiyah, yaitu diperbolehkan jual beli sesuatu bila wujudnya di dunia lebih banyak dari pada ketidakadaannya. Alasannya, apa yang tidak ada adalah mengikuti terhadap apa yang ada. ${ }^{67}$

4. Tidak ada kebutuhan mendesak terhadapnya.

Salah satu syarat adanya gharar dalam akad adalah apabila tidak ada orang yang membutuhkannya atau berkepentingan kepadanya. Sebaliknya, bila manusia membutuhkan transaksi akad yang dimaksud, maka tidak berpengaruh munculnya gharar. Hampir bisa dikatakan bahwa transaksi yang dilakukan oleh manusia adalah karena dibutuhkan. Dan pada dasarnya, salah satu prinsip syariah secara umum adalah menghilangkan kesempitan dan kesulitan. Firman Allah Swt., "Dan tidaklah Allah menjadikan dalam agama kesulitan/kesempitan..."68 Oleh sebab itu, bila ada larangan manusia melakukan transaksi, maka hal tersebut bertentangan dengan ayat di atas, yaitu justru membuat kesempitan dan kesulitan. Dengan demikian, ajaran syariat adalah adil dan rahmat bagi manusia, karena membolehkan manusia untuk bertransaksi dalam rangka memenuhi kebutuhan hidupnya, meskipun di dalamnya terdapat gharar.

Adapun pengertian kebutuhan (hajat), menurut al-Suyuti adalah "Manusia memenuhi kebutuhannya, yang apabila tidak dipenuhi atau melanggar larangan-larangan, maka ia akan mengalami kesulitan dan kesempitan, akan tetapi tidak membahayakan". ${ }^{69}$ Kebutuhan akan transaksi merupakan bagian dari hajat itu sendiri, yang bila manusia tidak bertransaksi, ia akan merasakan kesulitan dan kesempitan, karena lewatnya mashlahatmashlahat yang tidak bertentangan dengan syariat.

Kebutuhan yang tidak mendesak seperti defenisi dari al-Suyuti "tetapi tidak membahayakan" dimaksudkan untuk membedakan antara mana yang masuk kategori kebutuhan biasa dan mana yang dharurat. Sedangkan, defenisi dharurat adalah "Situasi dimana seseorang mencapai batas kritis yang apabila tidak melakukan pelanggaran, maka ia akan binasa atau yang mengancam jiwanya."70

Al-Suyuti adalah salah satu ulama yang membedakan aplikasi gharar pada transaksi yang bersifat dharurat dan gharar pada situasi yang dibutuhkan saja tetapi tidak mendesak. Sedangkan, ulama lain banyak yang tidak

${ }^{67}$ Muhammad Amin bin 'Umar 'Abidin al-Shahir bi Ibni 'Abidin, Radd al-Muhtar 'ala alDurr al-Mukhtar, Penerbit Bulaq, jil. 4, 1836., h. 140. Sejalan pula dengan pendapat sebagian ulama Hanabilah tentang kebolehan menjual sesuatu yang zahir. Menjual sesuatu yang mungkin ada hukumnya ada yang tidak pasti ketidak adaannya.

${ }^{68}$ QS. Al-Haj: 78.

69 Jalaluddin 'Abdurrahman bin Abu Bakar al-Suyuti, al-Ashbah wa al-Nazair (kairo: Percetakan al-Halabi, 1505), h. 77.

${ }^{70}$ Jalaluddin 'Abdurrahman bin Abu Bakar al-Suyuti, al-Ashbah wa al-Nazair....h. 77. 
membedakan antara kebutuhan dharurat dan kebutuhan biasa, sehingga idiom gharar banyak kita saksikan pada berbagai kebutuhan tersebut.

Kebutuhan pada dasarnya terbagi atas dua hal, yaitu kebutuhan yang sifatnya umum karena berhubungan dengan banyak orang, serta kebutuhan yang bersifat khusus karena hanya terkait dengan sekelompok orang atau hanya ada pada daerah tertentu. Adakalanya pula kebutuhan khusus tersebut terkait dengan individu atau beberapa orang yang tidak saling beruhubungan.

\section{Kesimpulan}

Sesuatu yang dibolehkan dan dihalalkan Allah Swt adalah jelas. Sebagaimana, jelasnya terhadap sesuatu yang dilarang atau diharamkan. Di antara halal dan haram, ada syubhat atau yang meragukan statusnya. Gharar yang dimaknai ketidapastian dan ketidakjelasan adalah bagian dari syubhat. Lebih detil bahwa gharar adalah tidak jelasnya konsekuensi atau akibat yang bisa diderita bagi salah satu di antara dua belah pihak yang bertransaksi pada masa yang akan datang. Tidak banyak orang yang mengetahui batasan-batasan gharar, kecuali setelah memahami apa maksud gharar dan mengetahui seluk beluk kasus yang terkait. Imam Nawawi yang menegaskan bahwa persoalan besar dalam transaksi adalah gharar, oleh sebab model akad ini banyak terjadi di masyarakat tapi hanya sedikit orang yang mengetahuinya. Oleh karena itu, siapa yang mengetahui hakekat gharar, ia memiliki kesempatan untuk menjauhinya dan akan memlihara diri dan agamanya. Sebaliknya, yang tidak care terhadap persoalan tidak jelas ini, maka membuka dirinya terjerumus kepada hal-hal yang merusak.

Untuk memahami lebih pasti batasan dan bingkai gharar dalam tulisan ini, sejalan dengan pandangan ulama, dikemukakan empat hal pokok. Yaitu, a) gharar ada pada bagian pokok suatu transaksi. Bila ghararnya ada pada bagian yang mengiringi transaksi pokok, maka ketidakpastiannya bisa ditolelir. b) Gharar hanya terjadi pada transaksi bisnis yang berorientasi mencari laba. Bukan pada transaksi sosial. c) Kandungan gharar pada sebauh transaksi adalah besar. Sebaliknya, volume ghararnya sedikit, tidak masalah atau boleh saja. d) Tidak ada kebutuhan mendesak terhadapnya. Larangan gharar diberlakukan bila gharar transaksi tidak terlalu mendesak. Sebaliknya, pada transaksi yang sangat dibutuhkan dan menjaga masalahat kebutuhan umat, maka unsur gharar diperbolehkan. Wallahu A'lam.

\section{Daftar Pustaka}

'Abidin, Muhammad Amin al-Shahir bi Ibnu. Hashiyah Rad al-Mukhtar 'ala al-Dar al-Mukhtar, Mesir: Matba'ah Mustafa al-Bab al-Halabi, Cet. 2, jil. 5, 1386 H.

'Abidin, Muhammad Amin bin 'Umar 'Abidin al-Shahir bi Ibni. Radd al-Muhtar 'ala al-Durr al-Mukhtar, Penerbit Bulaq, jil. 4, 1836. 
Abadi, Al-Fairuz. Al-Qamus al-Muhit, http://www.alwarraq.com, al-Maktabah alSyamilah, juz. 1, tt.

Aji, Ahmad Mukri. Urgensi Maslahat Mursalah Dalam Dialektika Pemikiran Hukum Islam, Bogor: Pustaka Pena Ilahi, 2012.

Al-'Ubaidi Rashid Abdul Rahman. (Tahqiq), Almustadrak tahdzib al-Lugha Lilazhari.

Al-Amidi, al-Ahkam fi Usul al-Ahkam Lilamidi, 2/275.

Al-Baji, Abu al-Walid Sulaiman bin Khalaf. Al-Muntaqa Sharh Muwatta', Jeddah: Maktabah al-Andalusi, jilid 5, tt.

Al-Baji, Sulaiman bin Khalaf. al-Muntaqa Sharh al-Muwatta', Penerbit as-Sa'adah, Jilid 1.

Al-Batili, Khalid bin Abdul 'Aziz. Ahadits al-Buyu' al-Manhiyu 'anha, Riyad: Dar al-Kunuz Isybiliya, Cet 1, 2004.

Al-Busti, Abu Sulaiman Hamdi bin Muhammad al-Khattabi. Ma'alim al-Sunan Sharh Sunan Abu Dawud, Beirut: Dar al-Kutub al-'Ilmiyah, Cet. 1 Jil.3, 1991.

Al-Darir, Siddiq Muhammad al-Amin. Al-Gharar fi al-'Uqud wa Atsaruhu fi alTatbiqat al-Mu'asirah, Saudi Arabiyah: al-Ma'had al-Islami Lilbuhuts wa al-Tadrib [IDB], Cet. 1, 1993.

Al-Gharar in Contracts and Its Effect on Contemporary Transactions, terbit tahun 1997.

Al-Hanbali, Abu al-Farji Abdurrahman bin Rajab. Al-Qawa'id al-Nuraniyah, Beirut: Dar al-Ma'rifah, tt.

Ali, Atabik. \& Muhdloi, Ahmad Zuhdi. Kamus Kontemporer Arab Indonesia, Yogyakarta: Pondok Pesantren Krapyak, cet. 3, 1998.

Al-Jauzi, Ibnu al-Qayyim. Zad al-Ma'ad fi Hadyi Khair al-'Ibad, Tahqiq Shu'aib alArnauti dan Ba'du al-Qadir al-Arnauti, Beirut: Muassasah al-Risalah, Cet. 14, jil. 5, 1996.

Al-Jazari, Majiduddin Ubai al-Sa'adat al-Mubarak bin Muhammad bin al-Utsair. Jami al-Usul fi Ahadits al-Rasul Saw, Tahqiq oleh Abd al-Qadir al-Arnaut Damaskus: Dar al-Bayan, jil. 10, 1969.

Al-Khudri, Usul al-Figh,

Al-Maliki, Ibnu Jazyi al-Garnati. Qawanin al-Ahkam al-Sar'iyah, Tahqiq: Abdul Rahman Hasan Mahmud, Cairo: Maktabah 'Alam al-Fikr, Cet. 1, 1986.

Al-Maqdisi, Abu Muhammad 'Abdullah bin Ahmad bin Muhammad bin Qudamah. Al-Mughni, Dar al-Manar, jilid 4, 1947. 
Al-Mawwaq, Abdullah Muhammad bin Yusuf. Al-Majallah al-'Adliyah, Beirut: Dar al-Kutub al-'Ilmiyah, cet. 1.

Al-Mi'yar al-Shar'i No. 31, "Dabit al-Gharar al-Mufsid Lilmu'amalat al-Maliyah".

Al-Naisaburi, Abu Bakar bin Muhammad bun Ibrahim bin al-Mundzir. Al-Ausat fi al-Sunan wa al-Ijma' wa al-Ikhtilaf, Tahqiq: Sagir Ahmad bin Muhammad Hanif, Riyad: Dar Tayyibah, Cet. 2, 1998.

Al-Nawawi, Abu Zakariya Muhyiddin bin Sharf. Al-Majmu' Sharh al-Muhadzdzab, Tahqiq: Muhammad bin Najib al-Muti'i, Cairo: Dar al-Turats al-'Arabi, jilid 9, 1994.

Al-Nawawi, Abu Zakariyah Muhyiddin Ibn Sharaf. Al-Majmu' Sharh alMuhadhab, Matba'ah al-Tadamun al-Akhwa, Juz 6, 676H.

Al-Nawawi, Abu Zakariyah Yahya bin Syarif bin Mari. Al-Minhaj Sharh Sahih Muslim bin al-Hajjaj, Sharh al-Nawawi 'ala Sahih Muslim, Beirut: Dar Ihyai al-Turath al-'Arabi, Juz. 10, Cet. 2, 1972.

Al-Nawawi, Al-Imam. Sharh al-Muhadzdzab, Beirut: Dar Ihya al-Turats al-'Arabi, jil. $9, \mathrm{tt}$.

Al-Nawawi, Sahih Muslim Bisharhi. Kairo: Dar al-Rayyan, Jil. 10, 1407H.

Al-Qanuji, Muhammad Siddiq Hasan Khan. Al-Raudah al-Nadiyah Sharh al-Darar al-Bahiyah, Riyad: Maktabah al-Kautsar, Cet. 4, jil. 2, 1996.

Al-Qarafi, Shihabuddin. Al-Furuq, Beirut: Dar al-Ma'rifah, jil. 3, tt..

Al-Qurtubi, Abu al-Walid Muhammad bin Ahmad bin Rashad. Al-Muqaddimat al-Mumahadat, Penerbit al-Sa'adah jil. 2, 1325.

Al-Qurtubi, Abu al-Walid Muhammad bin Ahmad bin Rushdi. Al-Muqaddimat alMumahadat Libayan ma iqtadathu rusum al-Muadawwanah min al-Ahkami alSyar'iyat wa al-Tahsyilat al-Muhakkamat Liummahati Masailuha al-Mushkilat, Beirut: Dar al-Maghrib al-Islami, jil. 2, cet. 1, 1408H.

Al-Rafii, Abdul Karim. Fath al-'Aziz sharh al-Wajiz, dikutip dalam kitab al-Majmu' Sharh al-Muhadzdzab, Beirut: Dar al-Fikr jil. 8, tt.

Al-Salami, Abdullah. Al-Taghrir fi al-Mudarabat fi Bursah al-Auraq al-Maliyah Tausifuhu wa Hukumuh, Workshop ke-20 Majlis al-Fiqh al-Islami yang diadakan di Makkah al-Mukarramah 25-29 Desember 2010, (Makkah alMukarramah: Rabitah al-'Alam al-Islami, Majma' al-Fiqh al-Islami, tt).

Al-Sarkhasi, Muhammad bin Ahmad bin Sahal. Al-Mabsut, Mesir: Penerbit alSa'adah, jil. 13, 1047.

Al-Suyuti, Jalaluddin 'Abdurrahman bin Abu Bakar. Al-Ashbah wa al-Nazair Kairo: Percetakan al-Halabi, 1505. 
Al-Taj wa al-Iklil ( jil. 6)

Al-Zahiri, Ibnu Hazm. Al-Mahalli, Tahqiq: Ahmad Muhammad Shakir, Cairo: Maktabah Dar al-Turats, jilid 8, tt.

Al-Zuhaili, Wahbah. Mausu'ah al-Fighi al-Islami wa al-Qadayah al-Mu'asirah, Damaskus: Dar al-Fikir al-Mu'asir, Jil. 4, Cet. 1, 2010.

Dharma, Setia. "Perlindungan Merek Terdaftar Dari Kejahatan Dunia Maya Melalui Pembatasan Pendaftaran Nama Domain", dalam Jurnal Cita Hukum, Vol. 2 No. 2 (2014).

Iqbal, Zami. \& Mirakhor, Abbas. An Introduction To Islamic Finance: Theory and Practice, (Terj. Oleh A.K. Anwar dengan judul Pengantar Keuangan Islam: Teori dan Praktek, (Jakarta: Kencana, Cet. 1, 2008),

Karim, Adiwarman .Islamic banking: Figh and Financial Analysis, Jakarta: Rajawali Press, Ed. 4, 2011.

Manzur, Ibnu. Lisan al-'Arab, Beirut: Dar Sadr, jil. 5, cet. 3, 1993,

Mustafa al-Zarqa, al-Madkhal al-'Am (jilid 1).

Mustafa, Ibrahim. Mu'jam al-Wasit (Istanbul: Dar al-Da'wah, jil. 2, tt)

Sharh Imam Nawawi ‘ala Sahih Muslim, jus. 5.

Sharh Sahih Muslim, 10/156-157.

Taimiyah, Ibnu. (syaikh al-Islam) Nazariyat al-'Aqd, Beirut: Dar al-Ma' rifah, tt.

Taimiyah, Ibnu. Majumu' Fatawa, Tahqiq oleh Abdul Rahman bin Muhammad bin Qasim, (Madinah Munawwarah: Majma' al-Malik Fahd, tt.

Yunus, Nur Rohim. Restorasi Budaya Hukum Masyarakat Indonesia, Bogor: Jurisprudence Press, 2012. 